\title{
ENERGY FROM MARINE BIOMASS
}

QUARTERLY REPORT FOR THE PERIOD

1 JULY 1978 - 30 SEPTEMBER 1978

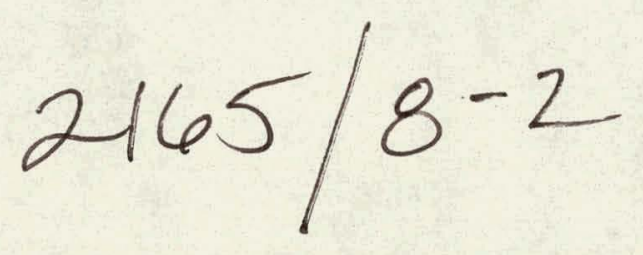

* SEE LETTERI DTD. NOVEMbER 29,1978 ALAN N. TOMPKINS

OCTOBER 20, 1978

GENERAL ELECTRIC COMPANY

RE-ENTRY \& ENVIRONMENTAL SYSTEMS DIVISION 3198 CHESTNUT STREET, PHILADELPHIA, PENNA. 19101

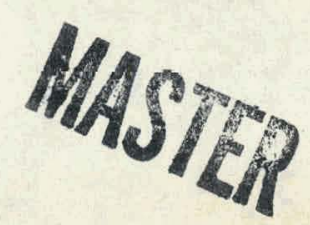

PREPARED FOR

U,S, DEPARTMENT OF ENERGY

FUELS FROM BIOMASS BRANCH SOLAR TECHNOLOGY

UNDER CCOPERATIVE AGREEMENT ET-78-F03-2765 


\section{DISCLAIMER}

This report was prepared as an account of work sponsored by an agency of the United States Government. Neither the United States Government nor any agency Thereof, nor any of their employees, makes any warranty, express or implied, or assumes any legal liability or responsibility for the accuracy, completeness, or usefulness of any information, apparatus, product, or process disclosed, or represents that its use would not infringe privately owned rights. Reference herein to any specific commercial product, process, or service by trade name, trademark, manufacturer, or otherwise does not necessarily constitute or imply its endorsement, recommendation, or favoring by the United States Government or any agency thereof. The views and opinions of authors expressed herein do not necessarily state or reflect those of the United States Government or any agency thereof. 


\section{DISCLAIMER}

Portions of this document may be illegible in electronic image products. Images are produced from the best available original document. 


\section{$\because$ NOTICE -}

This report was prepared as an account of work sponsored by an agency of the United States Government. Neither the United States Government nor any agency thereof, nor any of their emp.loyees, makes any warranty, expressed or implied, or assumes any legal liability or responsibility for any third party's use or the results of such use of any information, apparatis, product or process disciosed in this report or represents that its use by such third party would not infringe privately owned rights. 
ABSTRACT 


\section{ABSTRACT}

During this reporting period (1 July 1978 through 30 September 1978), a major milestone was completed in the Oceans Engineering area with the successful deployment of the Test. Farm. All systems were installed by 29 September 1978, and a detailed systems checkout is now underway prior to a full start-up of the Test Farm. Compatibility of the Test Farm with the planned transport and attachment procedures of the Macrocystis pyrifera plants has been completed and planting will begin on the full structure during the month of October. Success was also achieved in the Inoculum Development phase of the program with the production of two methane enrichments, one grown on an acetate medium and the other on a mixed acid substrate. These will be used in future mixed inoculum digester studies as an attempt to significantly decrease detention time. 
EXEEUTIVE SUMMARY 


\section{EXECUTIVE SUMMARY}

OCEAN ENGINEERING - Global Marine Development Inc. Morry Lebovits, Program Manager

Construction of the machinery buoy and substrate was completed at Bethlehem Steel, San Pedro Yard. This yard was also used as a staging area for deployment of all systems with the exception of the pipe. After deployment of the mooring system on 21 August 1978, the machinery. buoy and substrate were deployed. This occurred on 13 September 1978 and took approximately two days. The upwelling pipe was assembled at Dana Point Harbor and was initially deployed on 18 September. However, deployment was aborted due to weather conditions which developed after arrival on site. The pipe was returned to the beach and successfully redeployed on 27 September. The entire system was in place on 29 September, and the process of checking out the various subsystems was initiated. Kelp planting by Cal-Tech will be initiated during the month of October after completion of the subsystem mechanical and electrical operational verification tests.

Details of the Ocean Engineering activities are presented in the attached report (Attachment 12 .

INOCULUM DEVELOPMENT - General Electric Company - RESD

Dr. John Forro, Principal Investigator

The Inoculum Development Program, which was re-directed during the second quarter to concentrate on the rate limiting steps of cellulose degradation and acetate to methane conversion, has been successful in producing two methane enrichments, one grown on acetate medium and the other on a mixed acid substrate. These enrichments will be used in subsequent mixed inoculum digester studies in an attempt to significantly decrease digester detention time. Enrichments of organisms to increase the rate of degradation of cellulose were successfully started. These microorganisms are in the process of being isolated for subsequent scale up to large volume bench cultures.

Details of the Inoculum activities are presented in the attached report (Attachment 2). 


\section{ATTACHMENT 1}

OCEAN ENGINEERING

QUARTERLY PROGRESS REPORT

\section{PREPARED BY}

GLOBAL MARINE DEVELOPMENT INC. MORRY LEBOVITS, PROGRAM MANAGER. 


\section{GLOBAL MARINE DEVELOPMENT INC.}

QUARTERLY PROGRESS REPORT

1 JULY THROUGH 30 SEPTEMBER 1978

The major test farm components were emplaced at the test site offshore Laguna Beach, California, during this quarter. Deployment of the farm components, including assembly of the upwelling pipe, was accomplished in three phases as follows.

(1) Mooring System, 21 August - 1 september

(2) Machinery Buoy and Substrate, 13 september

(3) Upwelling Pipe, 13 september - 27 september

Deployment of the 3-point mooring system was reported in the August Progress Report. Upon completion of fabrication and assembly work at Bethlehem Shipyard, the machinery buoy and substrate were loaded onto a barge brought to the shipyard for that purpose and rigged for deployment on 12 september, and deployed on the following day. The Exclusion system design was completed in September. Fabrication of the system was withheld, however, in order to permit concentration of effort on the deployment of the test farm.

The first tow of the upwelling pipe for attachment to the substrate was aborted due to shifting and increasing wind and sea conditions. Inspection of the pipe after its return to the 
Dana Point harbor revealed damage over a 65 ft length located approximately $200 \mathrm{ft}$ from the upper end. The damage was attributed to repeated contact with a mooring buoy caused by the combined wind and sea forces. It was decided to remove the damaged $65 \mathrm{ft}$ length, join the remaining pipe segments, and make the few needed changes, e.g., add compensating length to the pipe lifting lines, rather than to replace the damaged section. The removal and welding was again done at the Dana Point assembly site and pipe deployment was successfully accomplished on 26 and 27 september.

Attachments to this Progress Report provide additional detailed descriptions of the above deployment activities and procedures. Included are:

(a) Mooring system Deployment Chronology

(b) Kelp Pipe Deployment Evaluation

(c) Kelp Program Pipe Fabrication Summary

Following installation of the major test farm components material ordering for the Exclusion system was initiated. Some work items that were incomplete or had been postponed earlier in order to expedite the at-sea installation were resumed. Examples of these are operational tests of the diesel engines/dispersion pump combinations, fuel system, final electrical system, and final painting in some areas. Such work has been conducted continuously since 
mid-September on a non-interference basis with the upwelling pipe installation.

All three engines with their pumps were successfully operated individually and in combination. Minor leaks in the fuel system and in the pressurized ISAR Buoy compartment have been corrected. 


\section{CONTENTS}

\subsection{INTENT}

2.0 CHRONOLOGY OF EVENTS

2.1 Pipe Fabrication

2.2 Predeployment Preparation

2.3 Tow out

2.4 Hook Up

2.5 Abort

2.6 Tow In

3. 0 PROCEDURAL CRITIQUE

4.0 OPERATIONÁL EVALUATION WITH HINDSIGHT

5.0 PROPOSED REMEDIAL ACTIONS

6.0 CONCLUSIONS 


\section{$1.0 \quad$ INTENT}

It is the intent of this document to provide a definitive chronology of events relating to the pipe deployment, to offer an evaluation of the procedures and operations that were used, and to propose remedial actions to the operation.

\section{0}

\subsection{PIPE FABRICATION}

On 13 September the machinery buoy/substrate was successfully deployed. Direction from GE to proceed with pipe fabrication was issued on 13 september. Fabrication started the next day and the pipe fabrication was completed two days later, on Saturday, September 16 , about midday.

\subsection{PREDEPLOYMENT PREPARATION}

Concurrent with pipe fabrication actions were necessary to prepare the pipe system for deployment. On Saturday, September 16, a procedural review with GE/GMDI was held to work out any final changes in the procedure. The primary change at this late date was in the details of the rigging of the lowering-link, its relation to the foot'piece, and the release of the load from the crane hook. This rigging scheme was tested and proven using the actual hardware, equipment and personnel. on sunday morning, September 17 , a status meeting was held to insure that all predeployment actions were being implemented. On Sunday afternoon, September 17, a final procedural review was held with all personnel involved in the operation. The deployment preparations were suspended about midnight, Sunday, september 17.. Mobilization for tow out was scheduled for 0530 Monday, September 18: A 
few actions such as final lock welding on shackles and securing devices on the foot piece were left to be done Monday morning. On Monday morning the final check list was completed with the exception of the midpoint belly band.

\subsection{TOW OUT}

Although everyone was present at 0530 Monday, September 18, the final preparations, removing lights from the pipe, and picking up anchors were not finalized until 0900. The tug Matilda and the diving crew were sent ahead to the site to observe weather, currents, and check the final preparations for hook up.

The pipe was towed out of Dana Point Harbor with the $D / B$ Samson towing the bottom end barge and the tug Trojan handling the top end horn. The top end horn was carried about 5 feet off the water by the bow A-frame. The pipe was towed dry and responded quite well during the tow. During the exit from the harbor one small can buoy was overrun without any consequence. The nine mile tow was accomplished at an average speed of about $4 \mathrm{kts}$ arriving on site at 1200. About an hour before arrival at the site radio contact with the tug Matilda indicated an increasing. wind from the southwest and little or no current. The final approach track was formulated with the Samson approaching to within $1 / 4$ mile, then turning northward. The top end of the pipe (and the Trojan) then stopped the tow and backed into the machinery buoy on a generally NE heading. A breast line from the Trojan to the NNW mooring buoy was successfully deployed. A stern line to the machinery buoy was also deployed. The Samson released the bottom end barge and the Tug Walrus assigned to hold position of the barge on the generally NE heading. The pipe was thus in position and hook up operations begun at approximately 1300 . 


\subsection{Hook Up}

The original plan required that the upper end of the upwelling pipe be supported on a pontoon during hookup (removal of end cap, installation of horn clips and connection of lifting and center cables). However, prior to towout, it was noted that the support pontoon was defective and it was removed.

As a result, during end cap removal and horn clip installation the pipe's upper end was supported out of the water with a short line connected between the horn padeye and the Trojan's A-frame hook. Up to 40 feet of pipe was out of the water depending on swell conditions and the Trojan's attitude.

After the end cap was removed and before the horn clips were installed relative motion occurred between the horn assembly and the upper pipe flange. The motion can be described as a back and forth sliding of the horn on the pipe of approximately 6-8 feet total motion.

The sliding occurred several times (more than 5 and less than (10). Once the horn clips were installed no other unexpected or untoward events occurred during the rest of the hookup.

The above motion appeared to cause impact loads on the upper pipe flange. Calculations show that stress loadings and strain due to the impact were very low and well within allowable limits. 
Hook up of the center cable and two $7 / 16 "$ wire lifting lines. was completed at 1630 hours. By then the wind had shifted from SW to the West or even WNW. The Tug Walrus was unable to hold position with the bottom end barge even though the pipe was making a long radius bend. It was decided to continue the lowering operation to the next step as the clearance between the pipe and the ESE mooring buoy was marginal but acceptable. The pipe top end was placed in the water and moved to progressively flood. The Samson was attached to the bottom end barge in an attempt to gain more clearance with the mooring buoy. This caused greater tension in the entire pipe and even though a second stern line was run from the Trojan to the machinery buoy the barge motions were increased to an unacceptable level. The pitch and heave of the Trojan aggravated the vertical forces on the Trojan A-Frame. The Samson could make no significant headway with pipe and was slacked off. The pipe then drifted down against the ESE mooring buoy and the decision to abort the operation was made by GMDI and agreed to by GE. A larger seagoing tug was ordered for subsequent, yet undefined, operations. ETA was given as approximately 1930 hours.

\section{$2.5 \quad$ ABORT}

The top end of the pipe was raised slightly above water to reduce the vertical forces on the Trojan A Frame. The 7/16" lowering wires were burned free. The center cable socket pin was removed with the 140' pendant tethered off firom the machinery buoy. The Tug Matilda released the Trojan's breast Iine and made up to the port stern quarter of the Trojan. The Trojan slipped her stern line and with tug Matilda pulling laterally made her way out of the farm area with top end of the pipe. Once clear, at 1730 hours, with samson at the head and downwind and Trojan at the rear and upwind but with the pipe flooded, the string was 
allowed to drift and assume a natural heading. The heading taken was approximately $10^{\circ}$ farther clockwise (i.e., to the south) than the existing ESE buoy/mooring alignment. The decision was then made to head for Dana point Harbor with the samson towing the pipe in the flooded condition. Options to try to reconnect in the ESE/SW segment with insufficient time left before dark, and laying to on site overnight were rejected. The tow was begun at 1800 hours.

\subsection{TOW IN}

The tow in was uneventful with the pipe riding quite easily. The tug spartan caught up to the tow at approximately 1930 hours and was asked to standby until safely in the harbor. The Samson was abeam of Dana Point light at 2030 hours indicating a $3 \mathrm{kt}$ towing speed for the pipe in flooded condition. Entrance to the harbor, even at night, was executed flawlessly by the Samson and Trojan. The tów was secured inside the breakwater at 2100 hours. 


\subsection{PROCEDURAL CRITIQUE}

The published procedures B-4050-6001 Alt. A were revised somewhat in a conference on saturday afternoon. The revised procedures were reprinted and issued for the sunday briefing. The major deviation from the procedure as finally specified was that the top end of the pipe was not resting on a float or pontoon but was carried in the bow "A" Frame of the Trojan. operationaliy this was a major. improvement during tow out and hook up. Since the bow "A" Frame was eminently suited to the hook up operation and flooding of the pipe it was decided not to try and place the horn end of the pipe alongside of the Trojan. The problem of access to the horn end for removal of the lower plate, installation of holding clips, 'retrieval of center cable, and attachment of the lifting wires was solved by having a man ride astride the horn out of the water. Once aboard the pipe it was a relatively safe, efficient work platform.

The procedure also called for lowering the horn end to a depth of 70!' with a 1" nylon line. Due to heavy swell conditions and the marginal acceptability (at that time) of the position in respect to the mooring buoy it was decided to leave the wire winch line from the Trojan "A" Frame attached as the pipe was flooded. This gave the option of recovery and about more chance of success.

These were the only procedural changes made in the field up to the time of abort. 
Aside from the established procedures there were several other factors that had contributing effects on the installation attémpt.

1) The men were tired. It had been a very long weekend of hard, physical work and pressure.

2) The $D / B$ Samson was due on station on another job. by Tuesday morning leaving no time for rest or a second attempt.

3) Although the current meter was on board, and a man to operate it, there was a shortage of boats that could be dedicated to the task. In hindsight, this information, gathered prior to arrival and during hook up, would have been very valuable.

4) The combined and current effects on the pipe were hard to access with the pipe in the dry condition. Once the pipe was flooded and the slight current from the northward took effect; the operation had to be. aborted.

5) A wind shift from sw to $w$ made holding of the pipe in proper azimuth impossible. A larger tug (as tried with the samson) only caused more violent actions at the top end of the pipe.

6) The self imposed requirement to leave harbor in dayli.ght hours took away the most quiet time of day, and was spent towing. It also negated any option for a secund hook up attempt. 
7) Not having a large twin screw ocean going tug available was not a contributory factor but placed undue requirements on the samson to act as towing vessel.

8) The absence of the midpoint belly band could have been used to help keep the pipe straight at the onset had there been a vessel available for such duty. In the final analysis, keeping the pipe straight during the early going would not have affected the eventual outcome, however.

\subsection{PROPOSED REMEDIAL ACTIONS}

The procedures have been refined to properly show the pipe being towed in the flooded condition with horn end supported by the bow A-Frame of the Trojan.

The steel lowering wire from the Trojan will be left attached as long as possible to aid in any abort procedure.

The Trojan (top end) will be moored to the ESE or the NNW mooring buoy until daylight to allow the pipe to take a natural position with the current.

The schedule has been rearranged such that the men will be able to rest before deployment.

Current data will be obtained the day prior to deployment and also during deployment. There will be a dedicated boat moored to the Sw buoy, with radio contact, to give real time current velocity and direction.

By allowing the pipe to take a natural set with wind and current 
in the flooded condition prior to moving into the machinery buoy will increase confidence in segment selection.

A $1000 \mathrm{HP}$ sea going tug with' a bow thruster has been selected as the towing vessel for the bottom end barge. This will provide better maneuverability and control of this end of the pipe:

The schedule has been arranged such that departure from Dana Point Harbor will be about 0200 with arrival on site slightly before sunrise. This will maximize the time on site and allow early morning operations when the wind is usually very slight.

'Two "belly bands" will be attached to the pipe at 500' intervals to aid in applying a transverse force to pull any belly out of the pipe rather than trying to do it by added, longitudinal tow force. These bands will be buoyant polypropylene ropes that will be easy for one of the small tugs to pick up.

\subsection{CONCLUSIONS}

Several general conclușions can be drawn from this operation.

a) The general concept of deployment still appears valid and only relatively minor changes to the procedure are warranted.

b) In formulating an overall deployment plan and procedure, it is important that as many options as possible be kept open for as long as possible such that any abort procedure neciessary will have the highest chance of success. 
c) Unique operation such as this in the open sea require that the best talent in rigging and seamanship that can be attained be assembled such that'any field judgements necessary to suit actual conditions have the highest chance of success. 


\section{MOORING SYSTEM DEPLOYMENT CHRONOLOGY}

$08 / 21 / 78$

Met with offshore Logistics personnel and $K$. Maggard, IM\&M Construction Crew Superintendent, to discuss final procedures. Advised that the $M / V$ Resolute would not be available until some time the evening of the $22 \mathrm{nd}$ or the morning of the $23 \mathrm{rd}$.

Arrangements were made for S.E.A.'s tug Matilda to be on site the morning of the $23 \mathrm{rd}$, to assist in launching the first mooring buoy and hold off while deploying the first leg. Arranged for $M / V$ Defender to onload at Beth., commencing the morning of the $22 \mathrm{nd}$.

$\underline{08 / 22 / 78}$

10:20 M/V Defender moored at Bethlehem Shipyard.

10:45 Mini Ranger III equipment installed on $M / V$ Defender.

13:00 Commenced offloading the ship's equipment on deck of $M / V$ Defender.

17:05. Commenced onloading mooring equipment. Onloaded two complete legs (except uniline) and one mooring buoy.

22:30 M/V Resolute arrived at Bethlehem Shipyard.

23:15 Completed onloading $M / V$ Defender. NOTE: Additional pier crane time was necessary ( . one hour) due to condition of crown line reel, which would not spin on deck. Reel had to be supported by crane to enable reeling on Defender's lower drum.

23:20 M/V Defender and Resolute shifted berths.

$08 / 23 / 78$

07:00 Commenced onloading mooring leg on $M / V$ ResoIute (1 leg, 1 mooring buoy). 
Page. 2 - .

08:47 Onloaded one Uniline to $M / V$ Defender.

10:02. $M / V$ Defender underway to site.

11:37 M/V Resolute underway to site (equipment left at Bethlehem for onloading that evening; one mooring buoy, one crown buoy, one Uniline).

12:15 $M / V$ Defender at site.

12:20 Tug, Maltilda II, pulled mooring buoy from fantail of Defender. Buoy turned over during process.

13:36 M/V Resolute at site.

13:55 M/V Resolute picked up tow of buoy from tug and Matilda released.

14:00 Winch hydraulic pump failure on $M / V$ Defender. Parts not available on board for repairs.

15:21 Disconnected Uniline from cable and freed $M / V$ Defender from buoy.

15:30. Transferred anchor crew to $M / V$ Resolute.

15:35 $M / V$ Defender departed site to obtain parts for winch and onload remainder of mooring equipment at Bethlehem Shipyard.

16:27 Commenced operations on $M / V$ Resolute to upright mooring buoy. By towing buoy from middle of upper surface, buoy turned over.

16:34 Buoy upright, recoiled 300 feet cable on top of buoy.

16:45 $M / V$ Resolute proceeded to point one mile off Abalone point and anchored for night.

17:57 M/V Defender moored at Bethlehem Shipyard to onload and make winch repairs. 
Page 3 . .

$08 / 24 / 78$

04:00 M/V Defender underway for site after onload of equipment and winch repairs.

04:45 $M / V$ Resolute underway for site.

06:15 Anchor crew transferred to Defender.

06:50 Launched mooring buoy from fantail of Defender to clear deck.

07:42 Reconnected Uniline from M/V Defender to mooring buoy. Commenced deploying Uniline.

08:15 Commenced letting out anchor chain from $M / V$ Defender.

12:06 Anchor in water and crown line slipped, allowing anchor to drop to sea floor. While still connected to mooring system.

14:00 Commenced retrieving mooring leg by spooling Uniline on upper winch drum.

17:00 2" hydraulic hose, main discharge hose from winch pump, ruptured. During succeeding winch run-a-way, hydraulic motor on winch damaged. Commenced repairs.

$08 / 25 / 78$

01:45 Repairs complete. Hydraulic motor parts taken from lower drum to fix upper drum. Commenced hualing in on Uniline.

02:30 Upper: winch drum cradied, bull gear moved, frame cracked, drum flanges frozen to frame and frame bent inwards, some Uniline (est 500 feet), all chain and anchor still in water. 
Page 4 . .

04:20 M/V Resolute transferred second mooring buoy to Defender.

04:36 $\mathrm{M} / \mathrm{V}$ Resolute underway to Long Beach for 200' $2 "$ cable left by Defender on piex. Cable to be used as noose.

06:36 M/V Resolute moored at Bethlehem Shipyard for cable.

10:50. M/V Resolute shifted to Crowley dock to onload grapnel hook.

$11: 53 \cdot M / V$ Resolute underway to site. Uniline on upper drum unspooled and flaked out on deck.

14:10 M/V Resolute on site.

16:00 Anchor crew transferred to $M / V$ Resolute to commence grappling for anchor chain.

16:30 Launched third mooring buoy from. fantail of $M / V$ Resolute to clear deck.

16:45 Passed third buoy to $M / V$ Defender.

17:15 Commenced first pass with grapnel. Unsuccessful.

18:30 Second pass with grapnel. Unsuccessful.

19:10. Third pass with grapnel. Unsuccessful.

21:32 Commenced rigging 200 foot pennant for noose around Uniline.

21:55. Commenced. lowering noose with towing line of $M / V$ Resolute.

23:00 Commenced hauling in on $M / V$ Resolute's towing wire. Crowley's barge, DB-5, and tug, 1062, standing by; Capt. J. Drahos, Glomar Explorer, on board barge to take over on site supervision.

23:29 Anchor on deck, commenced anchor chain retrieval process. 
Page 5 . .

$\underline{08 / 26 / 78}$

01:30 Secured from chain retrieval process $M / V$ Resolute and $M / V$ Defender connected by mooring leg, drifting.

01:40 Capt. Drahos on board to outline new procedures.

03:10 Transferred Mini-Ranger III equipment and operator to barge, $D B-5$, via tug, 1062. Capt. Drahos on DB-5. Barge and tug depart for center of mooring pattern. Barge deployed two of its mooring anchors; one north, one south.

06:40 Resumed chain retrieval process on board $M / V$ Resolute.

08:32 Detached Uniline from chain. Uniline hauled on board $M / V$ Defender. Attempts to free upper drum on Defender failed, drum jammed.

09:05 M/V Resolute moored to barge to transfer 15/8" cables, fish plates and fittings. One mooring buoy transferred from $M / V$ Defender to barge.

10:35 $M / V$. Resolute underway from barge, respooled Uniline on upper winch drum.

13:30. Passed end of Uniline to barge and commenced paying-out for north leg deployment.

15:56 Anchor in water. Commenced lower anchor by crown line. Commenced maneuvering $M / \mathrm{V}$ Resolute for anchor location using radar for ranges and bearings on barge at center of mooring pattern. Accuracy unsatisfactory.

17:52 Anchior on bottom, approximately due north of center, 0.4 miles from barge.

19:34 Attached crown buoy and launched. Transferred mooring buoys from $M / V$ Defender to tug, 1062 .

20:30 $M / V$ Resolute and Defender departed site for I.A. harbor. 
Page $6 . \therefore$

23:30 $M / V$ Resolute and Defender moored Consolidated Pier Wilmington. Commence upper drum removal procedures on $M / V$ Defender. Pier crane. capacity unsatisfactory to transfer anchor chain from $M / V$. Defender to outboard $M / V$ Resolute. Other mooring equipment transferred.

$\underline{08 / 27 / 78}$

$00: 00 \approx$ Crane unable to remove $M / V$ Defender's drum.

07:00 Shifted berths on boats to allow transfer across sterns of anchor chain.

10:50 M/V Resolute underway for site. Spooled Re= maining Uniline on upper winch drum.

13:40 M/V Resolute arrived at site.

14:20 $M / V$ Resolute along side DB-5 to transfer mooring gear. Picked up cable for mooring buoy on north tending leg to set anchor. Commence dismantling Mini-Ranger equipment to transfer to $M / V$ Resolute.

15:00 Commenced towing mooring buoy to set anchor.

15:30 Hauled fish plate on deck of M/V Resolute. $M / V$ Resolute discovered Uniline parted about 15' from cable connection. Mini-Ranger and operator on board $M / V$ Resolute.

16:55 Passed end of $300^{\prime} 1-5 / 8$ " wire rope to $D B-5$. Connected Uniline on upper drum to mooring buoy.

17:00 Commenced paying-out Uniline. For southwest tending leg.

17:35 Commenced running out anchor chain.

19:23 Archor in water. Commence lowering by crown line and maneuvering for anchor position.

20:06 Anchor on bottom.

21:33 Crown line cut, buoy attached and launched.

22:30 Commenced retrieval of north tending leg by crown line. 
Page 7 . .

$08 / 28 / 78$

00:25 Anchor on deck of $M / V$ Resolute. Commenced walking in chain.

03:04. Chain on deck. Commenced reeling in Uniline.

03:30 Uniline retrieved. $M / V$ Resolute underway for L.A. harbor.

06:25 M/V Resolute moored Consolidated Dock, Wilmington. Unspooled Uniline on dock. Observed upper drum of $M / V$ Defender's winch being removed, Uniline unspooled on pier.

11:53 M/V . Resolute shifted berths to Crowley dock to onload mooring equipment from $D B-5$.

14:00 Received all mooring rardware and one mooring to buoy on deck. Crowley tug, sioux, departed 18:20 for site with one mooring buoy undertow.

12:00 Meeting at GMDI, determined:

to

$16: 15$

1. To replace all three mooring's uniline with 1-1/2" wire rope.

2. Shackles were of high strength steel and should not have been welded on. (Bethlehem welded nut to shackle and anchor crew welded pin to shackle). Will require replacement of all shackles. Note: pins and nuts are $O K$ and can be re-used.

18:20 M/V Resolute shifted berths to Consolidated Dock, to receive replacement material and hardware for mooring legs, received one complete leg and replacement shackles. Replaced welded shackles on undersiàe of mooring buoy on deck.

$08 / 29 / 78$

07:00 M/V Resolute underway for site.

09:55 M/V Resolute arrived at site. Commenced rigging for deployment of north tending leg. Replaced activating cylinder on winch lower brake drum. 
13:20 Tug, Sioux, launched mooring buoy from fantail of $M / V$ Resolute. Commenced paying-out leg.

15:27 Commenced walking out anchor chain.

18:20 Anchor in water. Commenced lowering by crown line.

18:46 Commenced maneuvering $M / V$ Resolute for positioning of anchor.

19:37 Anchor on bottom. Rigged crown buoy.

21:30 Deployed crown buoy.

21:45 M/V Resolute departed site for L.A. harbor to receive remainder of mooring hardware. The Sioux remained on site.

$08 / 30 / 78$

00:45 M/V Resolute moored Consolidated Dock, Vilmington. Loaded remainder of mooring legs ecuipment.

06:05: M/V Resolute underway for site. Tug, Sioux, set north tending anchor leg.

08:45 M/V Resolute arrived at site. Tug, Sioux, upended. Free mooring buoy for replacement of shackles.

09:15 Connected line to crown buoy of north leg to determine anchor location. Buoy submerged and sank.

10:14. Retrieved buoy by polypropylene line attached on deck of $M / V$ Resolute.

11:20 Launch yellow buoy, intended for temporary center buoy for crown buoy.

11:50 Determined position of north anchor with $\mathrm{M} / \mathrm{V}$ to Resolute, by using small stuff polypropylene

1.2:33 as weak link, marking location when polypropylene parted. Anchor location plotted as $\mathrm{X}=$ $1,511,720, Y=490,815$ coordinates on Navigation Services, Inc. plot of site. 
Page $9 \cdot$.

13:46 Commenced rigging for deployment of southeast leg. Reshackled leg to buoy, upended buoy.

16:10 Commenced deploying leg from deck of M/V Resolute. Tug, Sioux, controlling mooring buoy and vessel separation.

17:00 Commenced walking out anchor chain.

19:23 Anchor in water. Commenced lowering with crown line.

20:00 Commenced maneuvering for anchor position as determined from location of north leg.

21:51 Anchor on bottom. Rigged crown buoy.

23:27 Launched crown buoy.

$08 / 31 / 78$

00:45 Commenced retrieval procedures for southwest leg.

01:55. Commenced hauling in crown line; due to twisting, necessary to disconnect and respool crown line.

02:55 Anchor on deck of $M / V$ Resolute, commenced retrieval of anchor chain; due to twisted condition, operations were very slow.

05:00 Suspended operations for sleep of anchor crew.

12:00 Renewed anchor chain retrievel process.

13:40 Commenced retrieving Uniline.

13:55 Uniline on upper drum commenced flaking Uniline on deck.

14:50 Commenced spooling now 1670' of 1-12," rahle on upper drum. Cable spool collapsed and unable to spool onto drum. Tug, Sioux, set anchor on Southeast leg.

16:75 Determined position of Southeast anchor by to pulling on crown buoy with polypropylene line.

19:32 Anchor location, $X=1,514,808 ; Y=448,035$. 
Page 10 . .

19:33 M/V Resolute in route, Wilmington to correct cable spool collapse. Tug, sioux, remained on site.

22:15 M/V Resolute moored Consolidated Dock, Wilmington. Crane crew and cable people standing by. Broken spool placed on turntable and re-spooled onto new spool. Reloaded M/V Resolute with new spool.

$\underline{0.9 / 01 / 78}$

02:40 M/V Resolute underway to site.

05:20 M/V Resolute arrived at site.

09:58 Commenced deployment of Southeast leg.

10:44 Let flaked out anchor chain on deck run free off $M / V$ Resolute.

10:45 Connected anchor to end of anchor chain.

11:06 Anchor in water, commenced lowering by crown wire.

11:20 Commenced maneuvering $M / V$ Resolute for position of anchor.

11:39 Anchor on bottom. Commenced positioning anchor.

12:55 Commenced rigging crown huny .

14:00 Crown buoy launched.

14:15 Determined position of Southwest anchor by to polypropylene line pull method $X=1510920$; $15: 35 \quad \mathrm{Y}=486800$.

15:45 Installed light on North anchor crown line buoy.

$16: 30$ Commenced connecting 300' center wire with $M / V$ Resolute picking up southeast line, Tug, Sioux, passing Southwest line to fantail of $\mathrm{M} / \mathrm{V}$ Resoiute.

17:47 Tug, sioux, received end of $M / V$ Resolute towing wire to run to north leg mooring buoy. Tug connected tow line to $300^{\prime}$ center wire. 
Page $11 .:$.

18:10 $\mathrm{M} / \mathrm{V}$ Resolute commenced hauling in on towing wire.

19:31 North leg 300' wire on deck of M./V Resolute commenced connecting third wire to Southeast and Southwest wires.

19:52 Connected $100 \mathrm{ft}$ pennant to shackled ends of $300 \mathrm{ft}$ lines and ball buoy to end $100 \mathrm{ft}$ pennant.

19:54 Launched ball buoy with light on top.

20:20 Tug, Sioux, released, M./V Resolute underway for Wilmington.

23:22 M/V Resolute moored Consolidated Dock, Wilmington. 


\section{KELP PROGRAM}

\section{PIPE FABRICATION SUMMARY}

It is the intent of this summary to generally outline the procedures used in the fabrication of the polyethylene pipe.

Several months prior to the start of the welding procedure several constṛuction sites were visited and evaluated. Ás a result of this evaluation the Marine Studies Institute Reserve Area at Dana Point Harbor was selected for the construction site. This area was carefully studied and layouts were made for the construction site (see attached sketches). Careful attention was given to the height of the top of the sea wall at low tide, but it was determined that the possible 12-foot drop shown in the sketches would pose no problems.

The critical items to watch during construction were:

1. The location of the final guide roller being as close to the sea wall as possible and the top of the rollers just high enough above the top of the sea wall so that the pipe would clear the sea wall during low tide.

2. The welding machine had to be located approximately 90 to 100 feet from the edge of the sea wall.

3. The end of the pipe with the foot piece could be put on the towing barge at high tide only. 
4. Three (3) lengths of pipe had to be welded together in oxder to place the foot piece and pipe on the towing barge and still be ready for the next weld at the welding machine. '

The pipe to be used arrived in Los Angeles approximately six weeks prior to its use. However, the pipe was not unloaded from the freight cars till approximately two weeks prior to use. As a result of leaving the pipes stacked in the freight cars, some of the pipes became out of round. A transition section, Series 45 to series 80 , was found to be approximately four inches out of round. The transition section was rounded out by jacking the section round and installing wood cross pieces. In any future fabrication the polyethylene pipe should be unloaded from the freight cars as soon as possible after del ivery.

The pipe to be fabricated consisted of a Series 40 flange, 13 pieces of Series 45 pipe approximately 60-feet long, one series 45 to Series 80 transition piece approximately 21 -feet long, 10 pieces of Series 80 pipe approximately 60 -feet long and one series 80 flange.

All material and equipment was assembled and set up at the construction site on Wednesday, 13 September 1978. Only nine sections 
of pipe was delivered to the construction site in order not to take up too much room and to provide for ease of handling during welding.

On Thursday, 14 September 1978, the series 45 flange was welded to the first section of pipe and a second section of pipe was welded to the first section. At this point the foot piece was temporarily secured to the flanged end of the pipe. A crane was hooked to the extreme end of the foot piece and the foot piece was lifted approximately 10 to 15 feet in the air. This procedure was done to determine the bending effect on the pipe. Upon completion of the test the foot piece was removed and a third section of pipe was welded. This completed the work for Thursday.

On Friday morning the foot piece together with a spacer to increase the flange thickness was attached to the flanged pipe cnd. The foot piece with the pipe attached was lifted up and placed on a barge moored by the sea wall by a 45 ton crane. The barge with the pipe attached was pulled out by a small tug till the shore end of the pipe was in the proper location on the welding machine for welding on the next section of pipe. A truck with a winch and wire line was used to restrain the pipe when being pulled out and to make exact adjustments to the pipe end in the welding machine. Nine (9) sections of pipe were welded on Friday following the above procedure. 
On Saturday, 16 september 1978 the remaining 12 sections of pipe were welded together without incident.

On sunday, 17 september 1978 the Series 80 flange was welded to the pipe and the horn was attached. Prior to pulling the pipe out by the tug and placing the horn on a dredge float, the center cable was pulled through the pipe from the shore by a winch on the tug. A messenger line was pulled.through each section of pipe after each weld was complete. A man was sent in the pipe to pull the messenger forward and to remove the internal bead from the pipe at each weld. The man used a skatcboard with a safety rope tied to one foot to carry out this pyocedure. After the center cable was pulled through the pipe the horn was placed on a dredge float, towed to a safe distance from the shore, and secured for the night.

During the welding process instruments and instrument cables were attached to the pipe.

On Monday morning, 18 september 1978 the pipe was towed to the deployment site. Due to deteriorating weather the upending procedure was aborted and the pipe was returned to Dana Point Harbor on Tuesday, 19 September 1978 .

On Wednesday, 20 september the pipe was inspected and damage was observed on the fourth section of pipe from the horn end. It was 
decided at that time to remove without replacing the damaged section of pipe.

The repair of the pipe was carried out from 25 september through 26 September 1978 in accordance with the attached procedure. The pipe was towed from the harbor early wednesday, 27 september 1978 to the deployment site and was successfully upended by approximately noon that day. 


\section{PIPE REPAIR PROCEDURE}

I. Drain Pipe

II Reverse Direction

III Bring Ashore

IV Center Cable Removeal

$\checkmark$ Pipe Repair

VI Launch \& Prepare for Deployment

1. Draining Pipe

A) The horn should be placed on a pontoon so that the stub end is approximately $I$ foot above the water line.

B) Place a pump on the barge with the footpiece and use $150^{\prime}-200^{\prime}$ of suction hose and start bailing the pipe. Bail until the pump starts to suck air.

C) Completion of drainage to be approved by GMDI \& GE (1/2 or more).

\section{Reversing Pipe Direction}

A). Before pipe is moved the follcwing steps must be taken:

1) Consult tide tables to choose a slack tide

2). Wind must be less than 4 kts.

3) Time of day must not coincide with peak marina traffic periods

4). Harbor patrol must be notified in advance

5) Preparation to tow must be completed at least 1 hour in advance of tow schedule, i.e. anchors up, boats in position, etc.

B) Preparation to tow:

1) Place cover plate on horn end

2) Make up bridal for horn padeyes 
3) Make up center pipe choker slings with polypropylene bights and floats for mid-pipe guidance

4) Position towing, following and picket poats along pipe and secure as appropriate.

5) Raise anchors

6) Tow readiness to be approved by GMDI \& GE.

C) Tow (Ref. Fig. 1)

1) Proceed eastward out of the channel for approximately 1 mile at approximately 2 knots.

2) Begin turn to south on approximately $1 / 4$ mile radius, completing $235^{\circ}$ change of course on a NW heading.

3) Turn to west on arriving at original tow out path, keeping well clear of end of breakwater. Tow speed approximately $1 \mathrm{kt}$.

4) Keep to port of mid-channel markers entering Dana Point Harbor and bring pipe to within 50' of sea wall. Maximum speed $1 \mathrm{kt}$.

5) Total time in tow approximately 2 hours.

6) Rear boat at all times must be prepared to arrest forward progress of tow and to be able to direct path of barge as required.

7) Short nylon towing lines, (50 to $100 \mathrm{ft}$ ) are desirable for maximum control:

D) Completion of Tow

1) Boats remain in position until all anchoring is completed

2) Final location and anchoring to be approved by GMDI \& GE. 


\section{Bring Ashore}

A) Shore Preparation

1) Place rollers as shown in Figure 2.

2) Position crane as shown in Figure 2

3) Position flatbed as shown in Figure 2, (winch).

4) Have all necessary equipment in working order, i.e., welding machine, chain saw, generator, etc.

B) Pipe Preparation

1) Place wire sling on horn padeye

2) Place choker strap on plastic pipe below horn

3) Place towing choker on pipe approximately $15^{\prime}$ from horn

4) Unlash pontoon

5) Plan lift at or near high tide

6) Adjust or remove anchors and have boats controlling pipe

7) Obtain GMDI \& GE approval before lifting

C). Lift Pipe Ashore

1) Lift pipe and carry well over ist roller and up to 2 nd roller before making contact with lst rolier.

2) Carry pipe up beach, watcining that reverse curvature over lst roller does not become excessive.

3) Lower pipe onto 3rd roller if above step is satisfied (It may be necessary to insert a back-up roller near the lst roller to carry the load if the curvature becomes excessive, as determined by DuPont). 
4) Put new purchase on pipe from winch track

5) Continue to pull ashore, using crane to lead horn over successive rollers and thru machine to area(s) to be cut.

6) Continue pumping during lifitng and carrying

7) Move anchors as required to accomodate pipe travel.

D) Pipe Holding Ouring Repair

1) Secure anchors, barge, winch truck, etc.

IV Center Cable Removal

A) Remove cover plate and place $275^{\circ}$ manila rope on center cable.

B) Pull cable out on barge end until manila rope bitter end is even with horn.

C) Flake out cable on barge deck and lash down lightly, (or spool, or stretch out and place in water).

$\checkmark$ Pipe Repair

A) Repair pipe as directed by Dupont representative

VI Launch \& Prepare for Deployment

A) Prepare for launch:

1) Move bottom cable bumper as required to accomodate new pipe length

2) Run messenger cable in to center cable and hook-up.

3) Recover center cable to approximately 20 feet beyond horn

4) Store excess cable and attach with $20^{\prime}$ soft line to cap plate and bolt cap plate to horn 
5) Remove anchors and have control boats standing by

6) Plan launch at or near high tide

7) Set up pipe as in III B I, 2, \& 3

8) Obtain GMDI \& GE approval before moving pipe

B) Launch

1) Move toward wall with crane carrying horn over rollers \& machine

2) Land horn on pontoon \& secure

3) Move horn out to $50^{\prime}-75^{\prime}$ from wall

4) Secure to GMDI \& GE satisfaction

5) Adjust anchor rodes to accomodate pipe trave. 


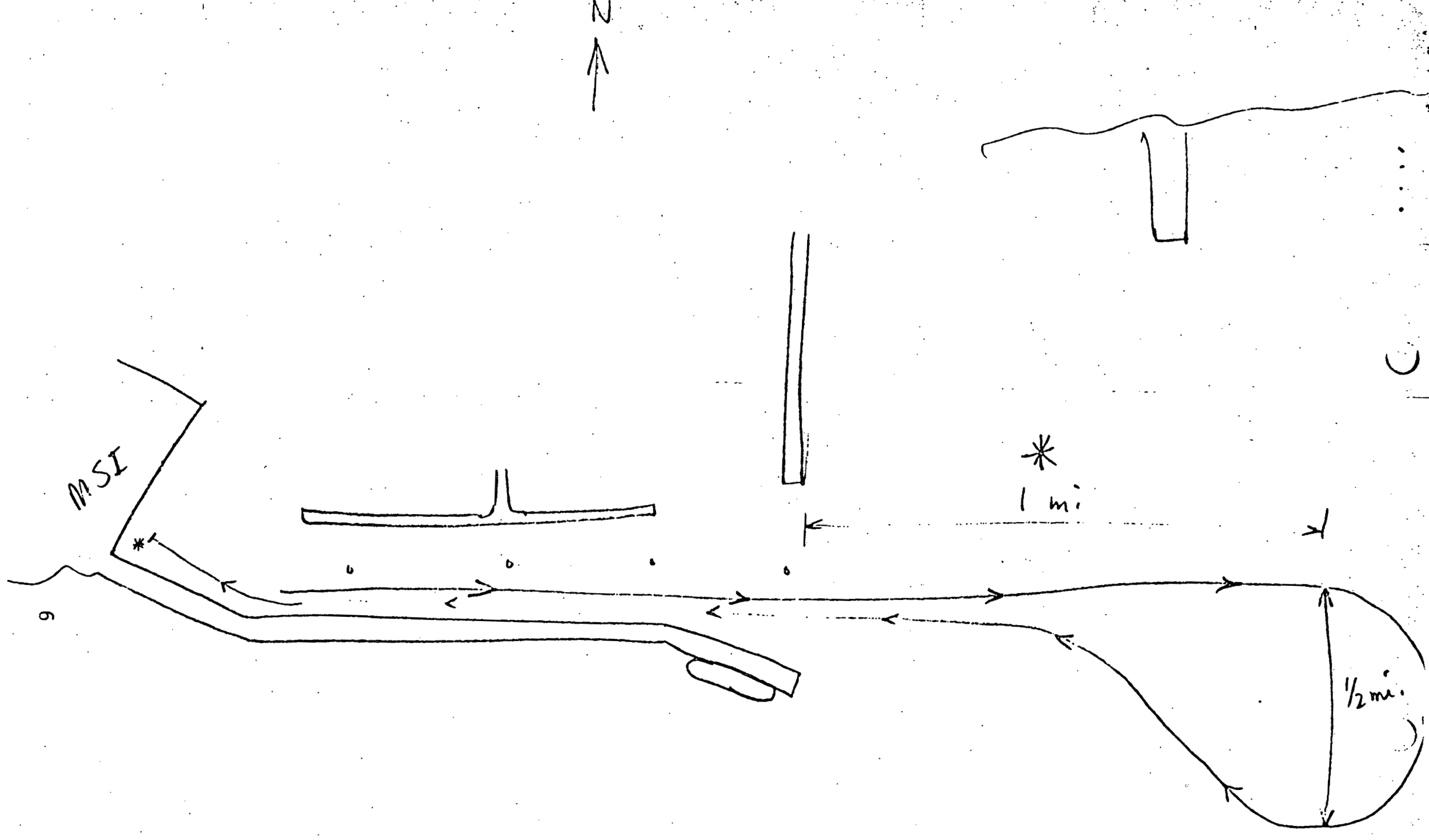

Figure 1 Tow Puth $\square$ Healy Tiut fiet, 


\section{ATTACHMENT 2}

INOCULUM DEVELOPMENT

QUARTERLY PROGRESS REPORT

\section{PREPARED BY}

GENERAL ELECTRIC COMPANY - RESD

DR. JOHN FORRO, PRINCIPAL INVESTIGATOR 
Summary 1

Feeding Trial Experiment $\quad . \quad \therefore \quad 2$

Methane Production - Batch Enrichment Studies. $\quad 8$

Large Scale Anaerobic Digestor $\quad \cdot \quad \ldots$

Change of Sample pH on Freeze/Thaw 11

Ambient Temperature Digestor $\quad . \quad \ldots \quad \ldots \quad$. $\quad . \quad 17$

New Equipment $\quad 17$

Cellulose Degradation Studies $\quad 18$

Other Activities $\quad \cdot 20$ 


\section{LIST OF TABLES}

TABLE NO.

Effect of Feeding Frequency and Volume on Methane Production and VFA Utilization by Methane Enrichments

A. Enrichment $11 \mathrm{E}$ in BWS

B. Enrichment MF 8 in BWS

C. Enrichment $1 \mathrm{lE}$ in FAS

D. Enrichment MF 8 in FAS

Production of Methane in Selected Media by

Two Methanogenic Enrichments 


\section{LIST OF FIGURES}

FIGURE NO.

SUBJECT

PAGE

1

Production of Methane in Selected Media by

10

Two Methanogenic Enrichments

2

Digestor Vesse1 - Sh. 1 of 2

12

3

Digestor Vesse1 - Sh. 2 of 2

13

4

Digestor Vessel - Packing We11 Components

14

5

Digestor - Packing We11 and Drive

15 


\section{MARINE BIOMASS PROGRAM}

\section{INOCULUM DEVELOPMENT PHASE}

QUARTERLY REPORT

JULY - AUGUST 1978

DR. JOHN R. FORRO

RALPH W. MAKINEN

MARVIN J. ENGEL

\section{SUMMARY}

During this reporting period (July - September 1978) emphas is was placed upon studies of the microorganisms concerned with the interconversion of low molecular weight intermediates to acetate, $\mathrm{CO}_{2}$ and $\mathrm{H}_{2}$ and their subsequent transformation to methane gas. Two significantly different methanogenic enrichments have been developed, both of which have responded favorably in terms of methane output under recently determined transfer conditions. One enrichment grows preferentially on acetate and the other on mixed acid media. These studies have also pointed out the requirement to develop improved defined media for the culture of these microorganisms in as much as the present formulations contain ingredients which make kinetic evaluations erroneous.

Attempts to initiate $\mathrm{pH}$-auxostat digestors designed for maximization of selected methanogen populations have not been successful primarily due to mechanical failures associated with the maintenance of anaerobiosis and the $\mathrm{pH} /$ feed control mechanism, both types of events leading to loss of culture viability. These malfunctions have been corrected and systems are being restarted. 
A 70 liter experimental digestor system has been designed and is in the process of construction. Upon completion, the system will be mated to an autofeeder system (in design phase), tested and shipped to WRRC for large scale digestion studies.

Upgrading of laboratory analytical capabilities continues with the acquisition of a Spectra-Physics central data processor and a Chemical Data Systems elemental analyzer.

During the period presentations were made to the Marine Biomass Program Project Advisors (July 1978), GRI Research Coordination Panel (September 1978) and to a PRIME Workshop at Villanova University (August 1978). An ambient temperature digestor culture (marine derived) is being scaled up for subsequent shipment to ICT for verification studies on low temperature digestion of kelp.

\section{FEEDING TRIAL EXPERIMENT}

The objective of this study was to determine the effect of varying. the feeding frequency, the feeding volume on the utilization of VFA's, and the subsequent production of methane by two methanogenic enrichment cultures. The feeding frequencies were 5, 10, and 20 day intervals, with volume changes of 25 and 50 percent of the medium volume. The head space was purged with $\mathrm{N}_{2} \mathrm{CO}_{2}(80: 20)$ after each feeding. Two different media were examined for each enrichment. BWS is the medium of Balch and Wolfe (1976) modified to contain $3 \% \mathrm{NaCl}, 0.1 \mathrm{ml}$ filter sterilized vitamin solution of Wolin et al (1963), and with the following substitutions: tryptone for trypticase, propionic acid for $\alpha$-methy 1 butyric acid, and valeric acid for isovaleric acid. FAS is the acetate medium of Ferry 
et al (1974) modified to contain $3 \% \mathrm{NaC1}$. All incubations were at room temperature. Gas pressure was determined manometrically. Methane and $\mathrm{CO}_{2}$ were quantitated by gas chromatography, with reported values corrected to $7.60 \mathrm{~mm} \mathrm{Hg}$ and $60^{\circ} \mathrm{F}$. VFA's were determined chromatographically using ether extracts (Anaerobe Laboratory Manual, VPI Anaerobe Laboratory, VPI, Blacksburg, Va. 1975), a SP1220 column, a thermal conductivity detector, and a temperature program operational mode. This procedure was utilized in place of the standard procedures as it allows detection and quantitation of all VFA's of interest including formic acid.

Table 1 A-D summarizes the methane and VFA data obtained in this study. For simplicity, VFA data is presented in terms of $\%$ change $(+$ or -$)$ per feeding period and only those acids with large fluctuations are shown.

This study produced one major, unexpected result. All VFA's from acetic to caproic were found to be produced at significant levels by both enrichments under all conditions examined. Thus the levels of all volatile acids initially present in a given culture increased. The most likely source of these acids is via the conversion of the amino acids supplied by the tryptone and yeast extract. The level of non-volatile acids (i.e. succinate, lactate, etc.) in the medium has not yet been determined, but will be in the immediate future as these are also likely to be produced: As a result of these findings, effort will be placed on significantly reducing or eliminating the tryptone/yeast extract from these media formulations. This finding also has a major implication on possible interpretations of literature reports describing the stimulatory effect of large quantities of yeast extract (and other materials) on methane production by mixed cultures. Since none of the authors specifically looked at the VFA 
TABLE 1. EFFECT OF FEEDING FREQUENCY AND VOLUME ON METHANE PRODUCTION AND VFA UTILIZATION BY METHANE ENRICHMENTS

\section{A. ENRICHMENT 11E IN BWS}

FEEDING VOLUME SAMPLE $M$ MOLES $\mathrm{CH}_{4}$ FREQUENCY CHANGE DAY PER FEEDING (DAYS) $\quad \frac{\text { (\%) }}{(\%)}$

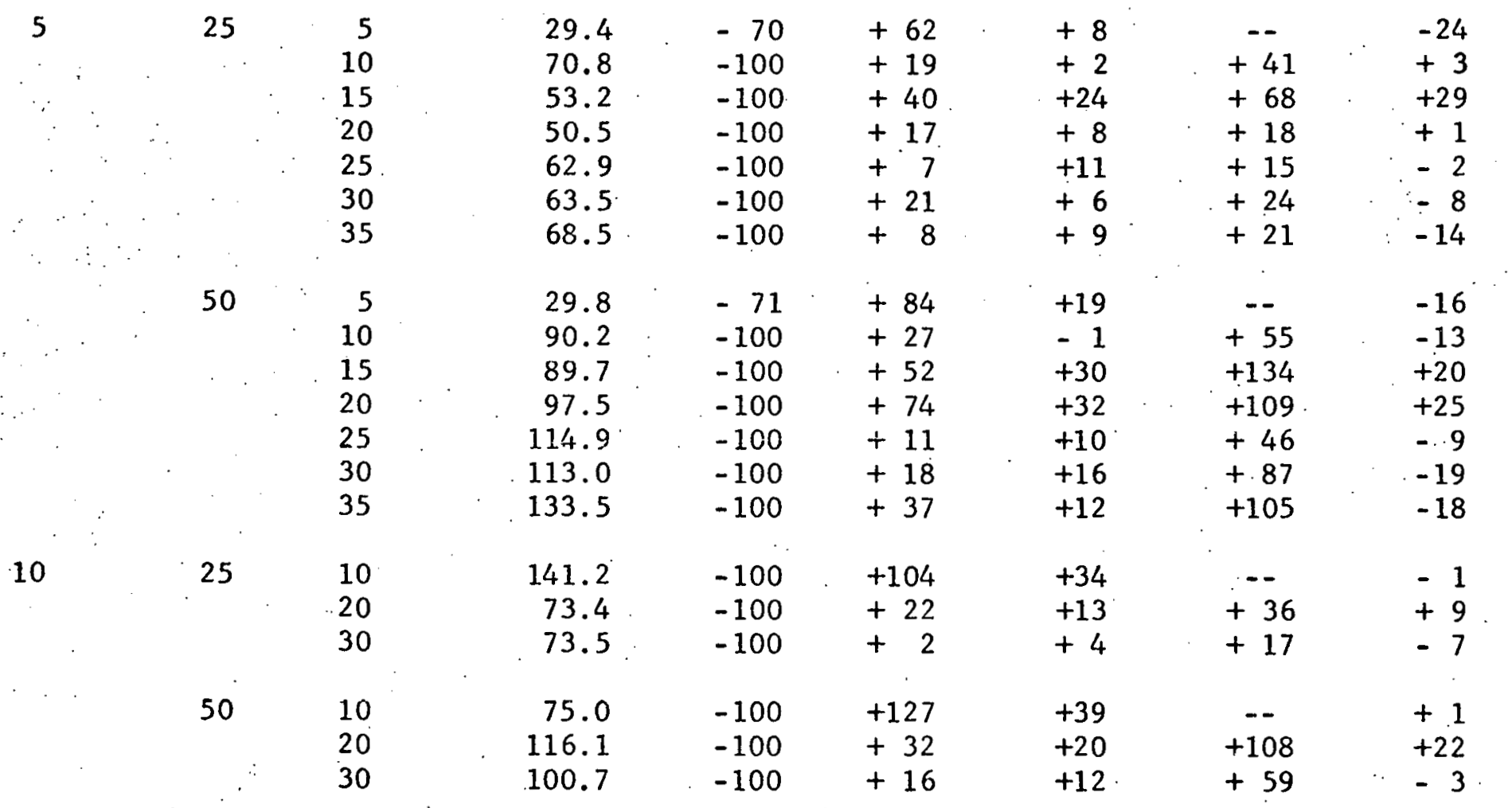

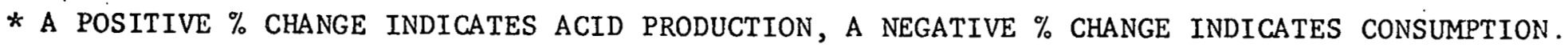


TABLE 1. EFFECT OF FEEDING FREQUENCY AND VOLUME ON METHANE PRODUCTION AND VFA UTILIZATION BY METHANE ENRICHMENTS

B. ENRICHMENT MF8 IN BWS

\begin{tabular}{|c|c|c|c|c|c|c|c|c|}
\hline FEEDING & VOLUME & SAMPLE & $\mu$ MOLES $\mathrm{CH}_{4}$ & \multicolumn{5}{|c|}{$\%$ CHANGE /FEEDING } \\
\hline$\frac{\text { FREQUENCY }}{\text { (DAYS) }}$ & $\frac{\text { CHANGE }}{(\%)}$ & DAY & PER FEEDING & FORMIC & ACETIC & PROPIONIC & BUTYRIC & VALARIC \\
\hline $\begin{array}{l}5 \\
\quad \\
\because \\
\therefore \\
\because\end{array}$ & $\begin{array}{l}25 \\
\ddots\end{array}$ & $\begin{array}{r}5 \\
10 \\
15 \\
20 \\
25 \\
30 \\
35\end{array}$ & $\begin{array}{l}-- \\
15.5 \\
20.0 \\
18.1 \\
17.7 \\
23.3 \\
28.8\end{array}$ & $\begin{array}{r}-19 \\
-\quad 3 \\
0 \\
-5 \\
+9 \\
-7 \\
0\end{array}$ & $\begin{array}{l}+32 \\
-4 \\
+13 \\
-4 \\
+30 \\
+5 \\
+8\end{array}$ & $\begin{array}{r}+6 \\
-3 \\
+13 \\
0 \\
+10 \\
-10 \\
+9\end{array}$ & $\begin{array}{l}-- \\
+157 \\
+98 \\
+43 \\
+67 \\
+69 \\
+36\end{array}$ & $\begin{array}{l}-27 \\
-7 \\
+11 \\
-2 \\
+29 \\
-28 \\
+6\end{array}$ \\
\hline . & -50 & $\begin{array}{r}5 \\
10 \\
15 \\
20 \\
25 \\
30 \\
35\end{array}$ & $\begin{array}{l}-- \\
16.2 \\
18.0 \\
20.5 \\
23.6 \\
30.9 \\
37.9\end{array}$ & $\begin{array}{r}-8 \\
0 \\
+\quad 4 \\
0 \\
+18 \\
0 \\
-16\end{array}$ & $\begin{array}{l}+24 \\
+10 \\
+21 \\
+7 \\
+38 \\
+17 \\
+9\end{array}$ & $\begin{array}{r}0 \\
-4 \\
+15 \\
+9 \\
+46 \\
-\quad 9 \\
-13\end{array}$ & $\begin{array}{l}-- \\
+182 \\
+156 \\
+94 \\
+139 \\
+72 \\
+75\end{array}$ & $\begin{array}{l}-25 \\
-9 \\
+10 \\
+2 \\
+26 \\
-9 \\
-30\end{array}$ \\
\hline $\begin{array}{l}10 \\
\therefore\end{array}$ & 25 & $\begin{array}{l}10 \\
20 \\
30\end{array}$ & $\begin{array}{l}15.1 \\
16.7 \\
22.1\end{array}$ & $\begin{array}{r}-4 \\
-10 \\
+\quad 7\end{array}$ & $\begin{array}{r}+40 \\
-9 \\
+27\end{array}$ & $\begin{array}{l}+30 \\
-12 \\
+29\end{array}$ & $\begin{array}{r}- \\
+88 \\
+142\end{array}$ & $\begin{array}{l}-2 \\
-17 \\
--\end{array}$ \\
\hline$\therefore$ & 50 & $\begin{array}{l}10 \\
20 \\
30\end{array}$ & $\begin{array}{l}15.2 \\
16.5 \\
29.9\end{array}$ & $\begin{array}{l}-1 \\
+2 \\
+5\end{array}$ & $\begin{array}{l}+31 \\
+5 \\
+33\end{array}$ & $\begin{array}{r}+17 \\
0 \\
+24\end{array}$ & $\begin{array}{r}+- \\
+134 \\
+126\end{array}$ & $\begin{array}{l}-12 \\
+2 \\
+6\end{array}$ \\
\hline
\end{tabular}


TABLE 1. EFFECT OF FEEDING FREQUENCY AND VOLUME ON METHANE PRODUCTION AND VFA UTILIZATION BY METHANE ENRICHMENTS

\section{c. ENRICHMENT 11E IN FAS}

\begin{tabular}{|c|c|c|c|c|c|c|}
\hline FEEDING & VOLUME & SAMPLE & $\mu$ MOLES $\mathrm{CH}_{4}$ & & CHANGE / FEEI & \\
\hline$\frac{\text { FREQUENC }}{\text { (DAYS) }}$ & $\frac{\text { CHANGE }}{(\%)}$ & DAY & PER FEEDING & ACETIC & PROPIONIC & BUTYRIC \\
\hline 5 & 25 & 5 & 24.7 & +54 & -- & $\ldots$ \\
\hline & & 10 & 35.3 & +9 & +39 & +30 \\
\hline ... & & 15 & 35.8 & +28 & +57 & +47 \\
\hline ' & & 20 & 46.5 & +16 & +43 & +68 \\
\hline & & 25 & 29.9 & +4 & +34 & +37 \\
\hline & & 30 & 31.7 & +5 & +43 & +47 \\
\hline & . & 35 & 31.0 & +4 & +72 & +31 \\
\hline & 50 & 5 & 18.8 & +51 & - & - \\
\hline & & 10 & 44.1 & +17 & +125 & +47 \\
\hline & & 15 & 47.9 & +39 & +112 & +104 \\
\hline & & 20 & 42.2 & +32 & +110 & +103 \\
\hline & & 25 & 48.7 & +21 & +106 & +136 \\
\hline . & & 30 & 45.4 & +12 & +78 & +107 \\
\hline & & 35 & 42.3 & +14 & +96 & +103 \\
\hline 10 & 25 & 10 & 36.0 & +78 & -- & -- \\
\hline & & 20 & 30.9 & 0 & +33 & +22 \\
\hline & & 30 & 31.7 & +25 & +102 & +42 \\
\hline & . 50 & 10 & 40.5 & +86 & $\therefore$ & $\because$ \\
\hline & & 20 & 40.9 & +10 & +86 & +71 \\
\hline & & 30 & 46.3 & +42 & +151 & +119 \\
\hline
\end{tabular}


TABLE 1. EFFECT OF FEEDING FREQUENCY AND VOLUME ON METHANE PRODUCTION AND VFA UTILIZATION BY METHANE ENRICHMENTS

D. ENRICHMENT MF8 IN FAS

\begin{tabular}{|c|c|c|c|c|c|c|}
\hline FEEDING & VOLUME & SAMPLE & $\mu$ MOLES $\mathrm{CH}_{4}$ & & CHANGE /FEEI & \\
\hline$\frac{\text { FREQUENCY }}{\text { (DAYS) }}$ & $\frac{\text { CHANGE }}{(\%)}$ & DAY & PER FEEDING & ACETIC & PROPIONIC & BUTYRIC \\
\hline $\begin{array}{l}: \\
: \\
:\end{array}$ & 25 & $\begin{array}{r}5 \\
10 \\
15 \\
20 \\
25 \\
30 \\
35\end{array}$ & $\begin{array}{r}9.8 \\
30.5 \\
42.8 \\
44.5 \\
47.4 \\
47.2 \\
50.3\end{array}$ & $\begin{array}{l}+54 \\
+11 \\
+27 \\
+7 \\
+38 \\
-7 \\
+13\end{array}$ & $\begin{array}{r}-- \\
+44 \\
+55 \\
+34 \\
+57 \\
+22 \\
+28\end{array}$ & $\begin{array}{l}-- \\
+56 \\
+15 \\
+33 \\
+36 \\
+24 \\
+10\end{array}$ \\
\hline . & 50 & $\begin{array}{r}5 \\
10 \\
15 \\
20 \\
25 \\
30 \\
35\end{array}$ & $\begin{array}{l}5.1 \\
42.4 \\
56.7 \\
49.1 \\
65.7 \\
66.6 \\
67.1\end{array}$ & $\begin{array}{l}+62 \\
+24 \\
+33 \\
+21 \\
+34 \\
+23 \\
+30\end{array}$ & $\begin{array}{l}-- \\
+126 \\
+104 \\
+105 \\
+85 \\
+134 \\
+101\end{array}$ & $\begin{array}{l}-- \\
+125 \\
+58 \\
+107 \\
+43 \\
+138 \\
+54\end{array}$ \\
\hline 10 & 25 & $\begin{array}{l}10 \\
20 \\
30\end{array}$ & $\begin{array}{l}25.4 \\
37.7 \\
44.4\end{array}$ & $\begin{array}{l}+86 \\
-\quad 1 \\
+35\end{array}$ & $\begin{array}{r}- \\
+36 \\
+75\end{array}$ & $\begin{array}{r}-- \\
+25 \\
+38\end{array}$ \\
\hline . & 50 & $\begin{array}{l}10 \\
20 \\
30\end{array}$ & $\begin{array}{l}25.4 \\
45.7 \\
55.8\end{array}$ & $\begin{array}{l}+89 \\
+21 \\
137\end{array}$ & $\begin{array}{l}-- \\
+106 \\
+131\end{array}$ & $\begin{array}{r}-- \\
+92 \\
+150\end{array}$ \\
\hline
\end{tabular}


levels during their studies, they may have been observing a substrate effect, not a trace requịrement effect.

In this study, iso-valeric, iso-caproic, and caproic acids were also present in significant levels, but were not quantitated as standards were not immediately available. They will be quantitated in all future studies.

Formic acid was completely utilized by enrichment $11 \mathrm{E}$, and was essentially untouched by enrichment MF8. Valeric acid in BWS with enrichment 11E and MF 8 was the only other acid exhibiting a net consumption during this study.

Methane production per feeding period increased above the initial levels, and appeared to reach a steady state by the end of the second feeding period. Only in the case of a 5 day feeding schedule with $11 \mathrm{E}$ cultured on BWS did a doubling of the feed volume result in a doubling of the methane yield. All other cases produced less than a doubling of methane per doubling of feed volume. In all instances, enrichment $11 \mathrm{E}$ produced more methane from BWS than from FAS, and enrichment MF 8 produced the opposite pattern. This finding, in conjunction with the volatile acid data, suggests the microbial populations in the two enrichments are completely different.

\section{METHANE PRODUCTION - BATCH ENRICHMENT STUDIES}

As part of the methanogen enrichment study, batch cultures of two enrichments ( $11 E$ and MF8) were established in BWS and FAS media (described previously) with incubation at room temperature $\left(\simeq 24^{\circ} \mathrm{C}\right)$ for a period of a month. Total methane gas produced was determined at 5 day intervals in order to establish both baseline methane generation rates and yields. These data are presented in Table 2 and are graphically displayed in Figure 1. 
TABLE 2. PRODUCTION OF METHANE IN SELECTED MEDIA BY TWO METHANOGENIC ENRICHMENTS

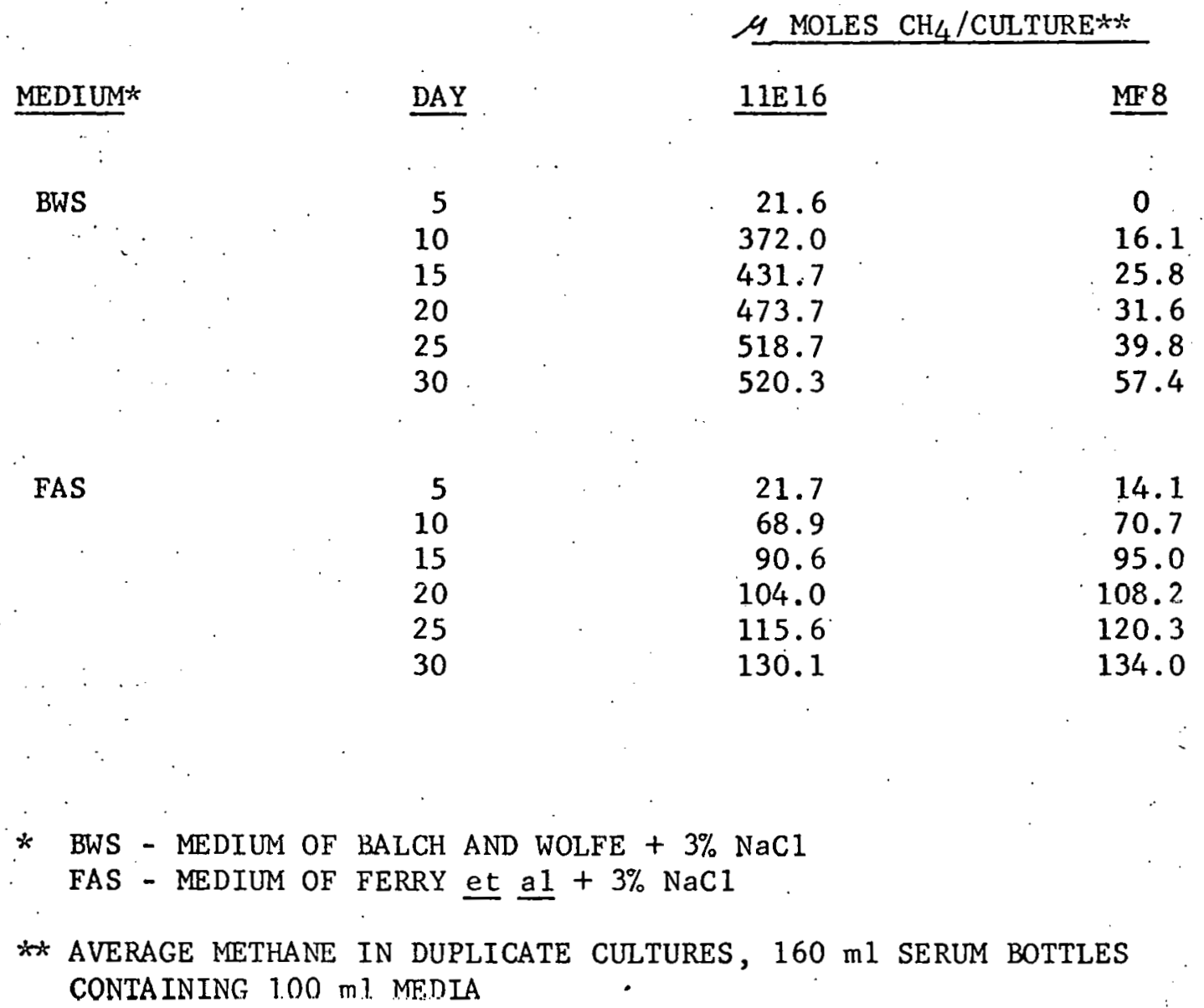


Floure 1. Production of Methane in Selected

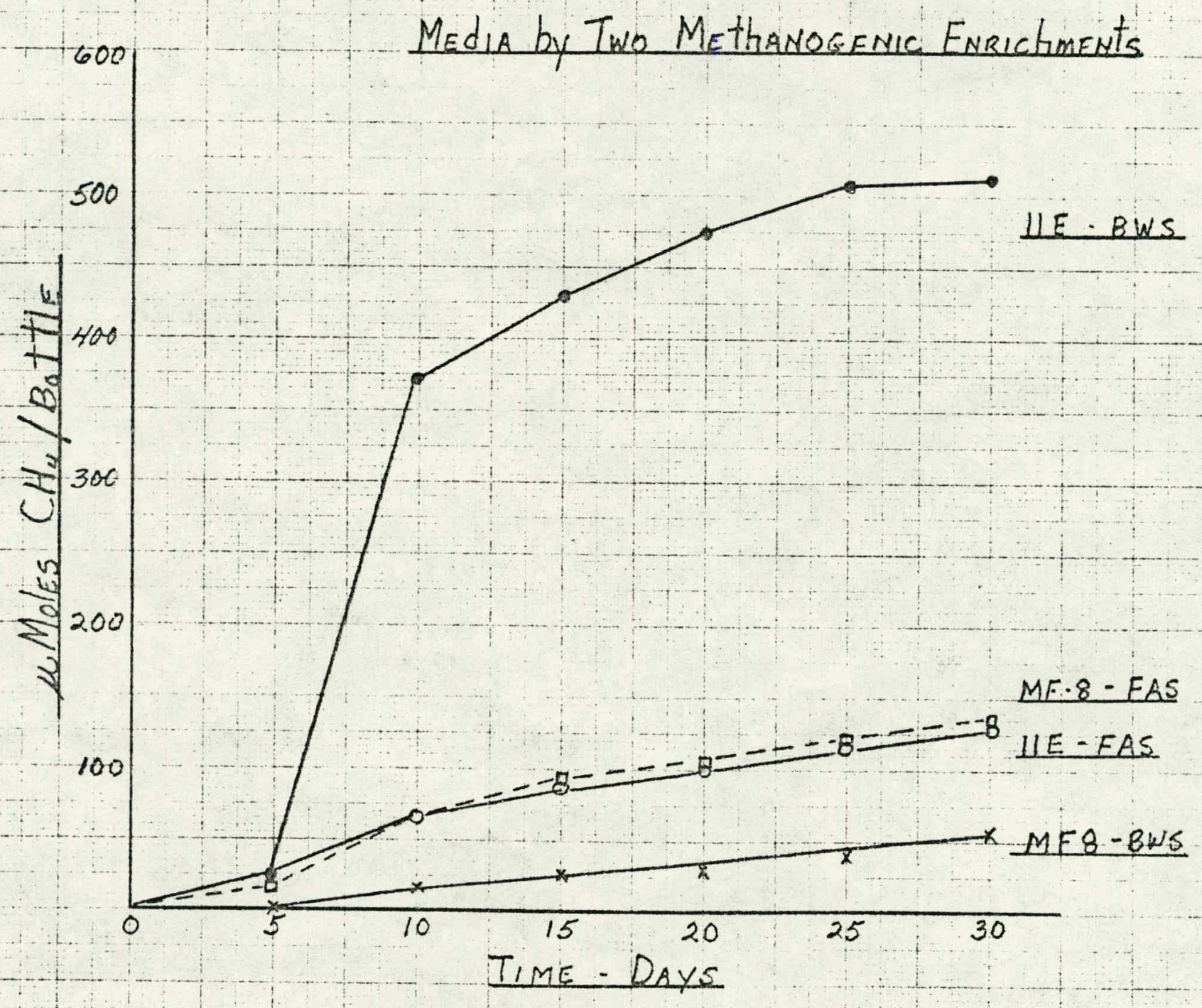


Clearly, the two enrichments examined are distinct in terms of their ability to produce methane in a mixed acid medium (BWS) and a1though their performance in an acetate medium (FAS) is quite similar, it suggests these enrichments represent different microbial consortiums. This is supported by the acid utilization and methane production data obtained during transfer studies.

Studies are now in progress in which the rate and yield of methane gas production is being evaluated in batch culture as a function of successive transfer at the determined frequency and volume.

\section{LARGE SCALE ANAEROBIC DIGESTOR}

In order to meet commitments for scale-up of bench scale laboratory digestors, effort was placed on the design, component procurement and construction of a 70 liter (60 1iter working volume) digestor. The design, detailed in Figure 2 to Figure 5, took into consideration requirements for monitoring of performance parameters and potential for introduction of increased sized kelp feed. Materials selected for construction were chosen for compatability with microbial systems, strongly reducing environments and the high salinity of the reaction mixture. A list of major components and ancillary equipment is provided in Table 3 . As of the date of this report, the fabrication of the fermentor has not been completed, but it is anticipated that this task will be completed by FW42.

\section{CHANGE OF SAMPLE PH ON FREEZE/THAW}

During a period when our $\mathrm{pH}$ meter was inoperable, some experimental digestor samples were frozen for later analyses. After thawing, the pH values of these samples appeared to be inconsistent with previous data. As 


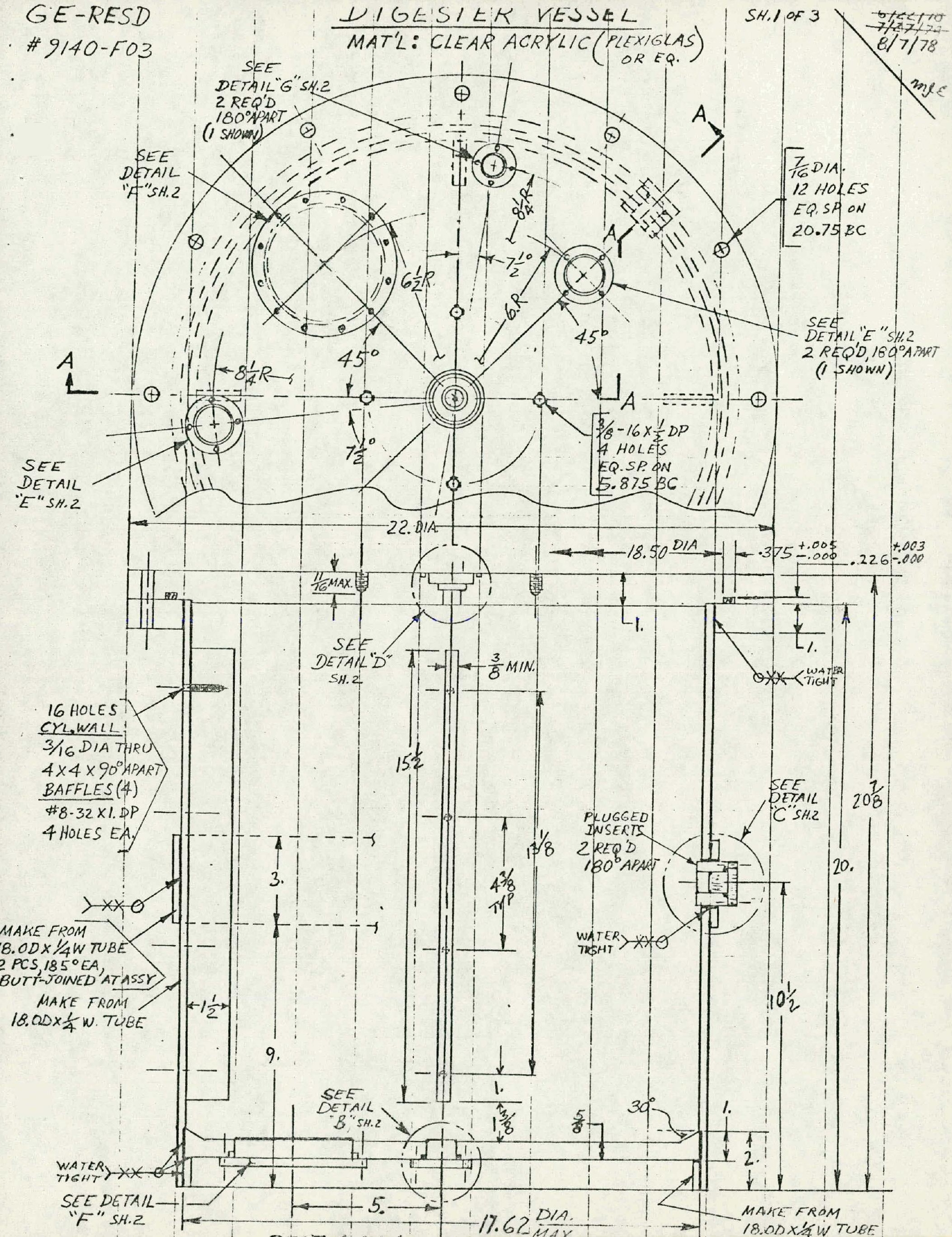


GE-RESD \#9140-FO3

\section{C'BORE}

94 DIA X.060DP

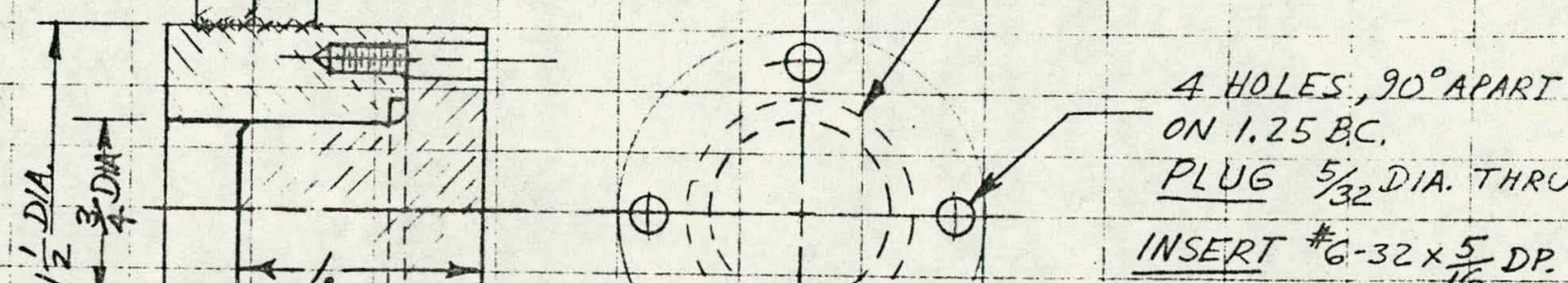
$-1 \mathrm{~N}$

1
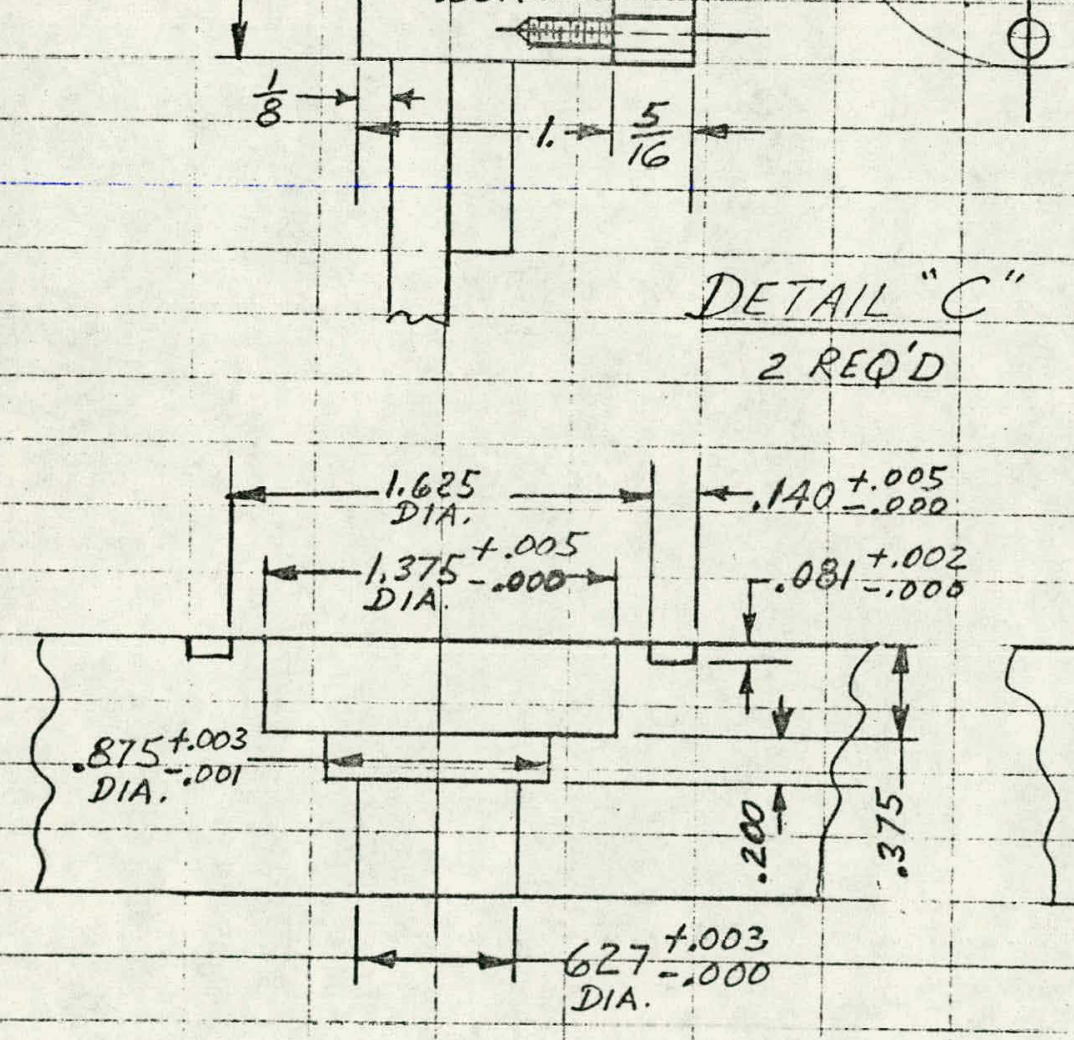

$$
\frac{\text { DETAIL "C" }}{2 \text { REQD }}
$$

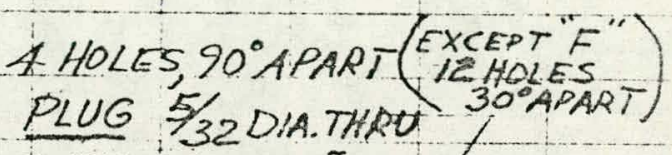
FLANGE \#6-32x $\frac{5}{16} D P$



DETAIL "D"

\begin{tabular}{|c|c|c|c|c|c|c|}
\hline \multirow{2}{*}{ DETAIL } & \multirow{2}{*}{$\begin{array}{l}\text { NO } \\
R E Q^{\prime} D\end{array}$} & \multicolumn{5}{|c|}{ DIMENSION } \\
\hline & & "U" & $" v "$ & $" w "$ & $" x$ " $x$ & \\
\hline$" B "$ & $\frac{7}{1}$ & 2. & 1.625 & 1.19 & 1. & 066 \\
\hline$E^{\prime \prime}$ & 3 & 2 & 1.625 & 1.19 & 1. & 600 \\
\hline "F" & 2 & 5. & 4.688 & 4.38 & 4. & 120 \\
\hline "G" & 2 & $11 / 2$ & 1.250 & .94 & $3 / 4$ & .060 \\
\hline
\end{tabular}









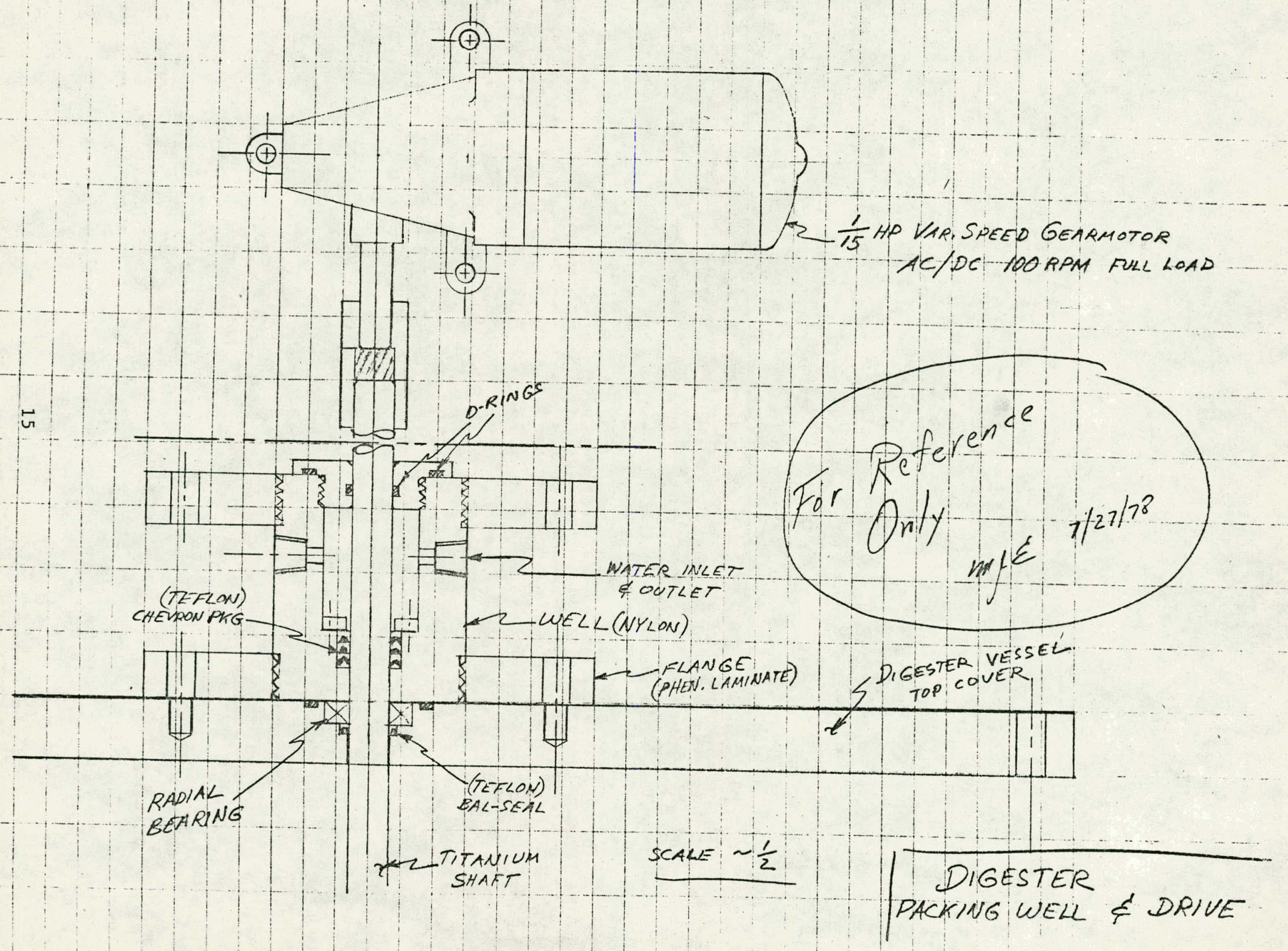


TABLE 3. MAJOR PARTS LIST - 70 LITER DIGESTOR

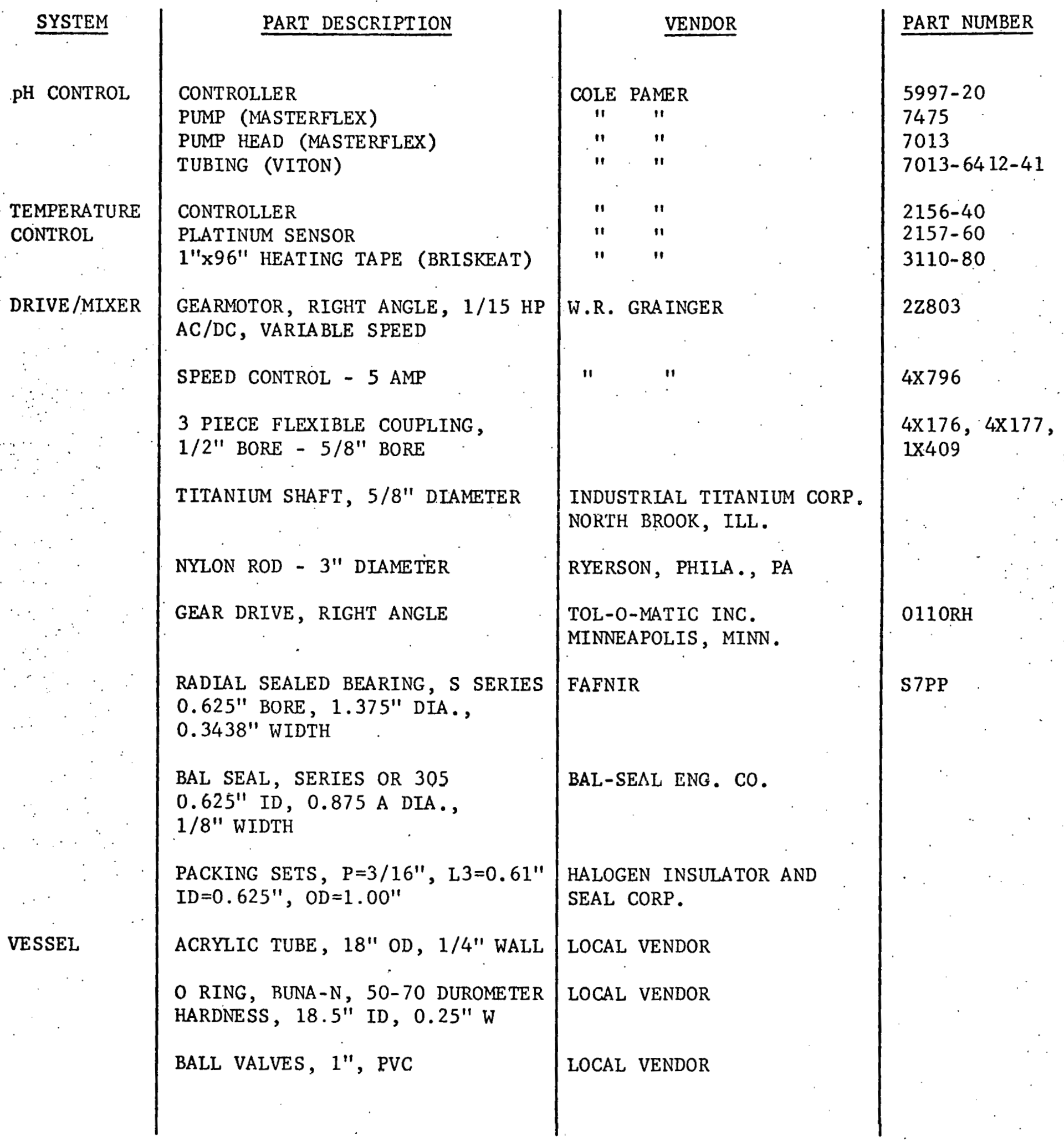


such, the $\mathrm{pH}$ of several fresh fermentor samples was determined prior to and after freeze/thaw. It was found under these conditions that $\mathrm{pH}$ values increased by an average of $0.6 \mathrm{pH}$ units $(\simeq \mathrm{pH} 6.6$ to $\simeq \mathrm{pH} 7.2)$. Although the exact mechanism of this shift is not known, it probably involves a loss of volatile acids or $\mathrm{CO}_{2}$ upon thawing. One is thus cautioned on interpretation of data obtained on frozen samples unless care is taken to prevent losses due to volatilization (i.e. storage in sealed vials with 1 imited head space).

\section{AMBIENT TEMPERATURE DIGESTOR}

In order to verify data generated in this laboratory on ambient temperature generation of methane from kelp utilizing a marine derived inoculum, a second digestor was initiated and was gradually built-up to volume and was being monitored to established steady state activity when a leak developed in the digestor gasket. Transfer of culture to a new digestor was accomplished with minimal loss of activity, but this event has occasioned a delay in development of steady state and subsequent shipment to IGT.

As a result of the difficulties encountered with the digestor described above and other problems, new digestors are being constructed to replace those in use. These are being fabricated using custom-made glass vessels, rubber stoppers and PVC ball valves for introduction of feed. Mixing will be accomplished as before using magnetic stirrers.

\section{NEW EQUIPMENT}

In a continuing effort to upgrade and expand the analytical capabilities of this laboratory, two new laboratory instruments were procured and installed. 


\section{a) Chemical Data Systems - Elemental Analyzer and Peak Identifier}

This instrument will determine the elemental composition $(\mathrm{C}, \mathrm{H}, \mathrm{O}, \mathrm{N}, \mathrm{S}, \mathrm{X})$ of injected gaseous or liquid samples, and will determine several of the basic structural properties (ester, ketone, alcohol, amine, mercaptan, length of carbon skeleton). It is currently being modified to take the effluent (via a stream splitter) from a gas chromatograph. It will then perform these analyses on each resolved peak in a gas chromatogram.

\section{b) Spectra-Physics - Data Acquisition System}

The basic Spectra Physics SP4000 data system automatically acquires and reduces chromatographic data. This system is far superior to our Varian CDS11l integrator as it allows multi-point calibration curves for peaks which don't go through the origin, allows integration of negative peaks, has a larger repertoire of baseline and data manipulation options, and is capable of controlling valves, autosamplers, etc. This system is expandable to handle 16 different instruments simultaneously. Early next year it is planned to expand from the current single instrument capability to a system able to handle 3 instruments simultaneously.

\section{CELLULOSE DEGRADATION STUDIES}

As described in previous reports, effort is being devoted to the study of cellulose degradation with marine derived anaerobic cultures, as cellulose hydrolysis appears to be a major rate limiting step in the conversion of ke1p to methane. 
Several enrichment cultures capable of degrading filter paper strips have been established and are being maintained. Attempts to isolate the bacterial strains effecting the primary cellulose hydrolysis steps have been tried utilizing conventional roll tube techniques (Hungate) containing bal1-milled cellulose media. These have not proved successful. Although numerous colony types develop in these tubes, none have been found to be capable of hydrolyzing cellulose when cultured individually. In addition, at no time have clearing zones indicative of extracellular cellulose activity been noted in these media.

First attempts to utilize hydrogen scavaging techniques (i.e. palladium black) to alleviate potential hydrogen repression of growth/cellulose utilization have not yielded cellulose degrading strains.

Additional experiments are in progress in which these techniques are being coupled with the use of a less highly crystalline cellulose substrate (i.e. Walseth Cellulose) in place of filter paper cellulose. Being less crystalline, this material should be more amenable to the zone during detection schemes being employed. Alternative isolation methods such as direct plating on solid cellulose substrates and multiple dilution techniques are being contemplated.

Preliminary observations with enrichment cultures as to the effect of temperature on the disintegration of filter paper strips indicate a more rapid hydrolysis at $35^{\circ} \mathrm{C}$ than at room temperature. Verification and quantitation of this observation will be pursued after isolation of the appropriate strains. 
Severa1 presentations were made during this reporting period:

a) Project Advisors Quarterly Meeting - Newport Beach, Calif., July 19-20, 1978 .

b) PRIME Workshop (Philadelphia Regional Introduction for Minorities to Engineering), Villanova University, August 24, 1978 - "Production of Substitute Natural Gas from Marine Biomass".

c) Gas Research Institute Research Coordination Pane1 - Newport Beach, Calif., September 21, 1978.

In addition, $R$. Makinen attended a 2-day workshop on the use and application of Spectra-Physics central data processor. 